\title{
Effectiveness of Data Mining - based Cancer Prediction System (DMBCPS)
}

\author{
A.Priyanga \\ M.Phil (CS) Research Scholar \\ SCSVMV University \\ Enathur, Kanchipuram
}

\author{
S.Prakasam, Ph.D \\ Assistant Professor \\ Department of CSA, SCSVMV University \\ Enathur, Kanchipuram
}

\begin{abstract}
Cancer is one of the deadly diseases in the world today. Cancer is caused because of some genetic factors and/or environmental factors and/or today's modern lifestyle. Cancer has become the primary reason of death in developed countries. The most effective way to reduce cancer death is to detect it earlier. The earlier detection of cancer is not easier process but if it is detected, it is curable. Many works have been done in predicting cancer; different data mining approaches and algorithms were adopted by different people. Each work has some limitations such as lack of intelligent prediction, and inefficient in structure that motivated to take up this problem and to implement the Data mining based cancer prediction System (DMBCPS). We have proposed the cancer prediction system based on data mining. This system estimates the risk of the breast, skin, and lung cancers. This system is validated by comparing its predicted results with patient's prior medical information and it was analyzed by using weka system. The main aim of this model is to provide the earlier warning to the users, and it is also cost efficient to the user.
\end{abstract}

\section{General Terms}

Data mining, Cancer

\section{Keywords}

Breast cancer, Lung Cancer, Skin Cancer, J48, Id3, Navie bayes

\section{INTRODUCTION}

Cancer is a potentially fatal disease caused mainly by environmental factors that mutate genes encoding critical cellregulatory proteins. The resultant aberrant cell behavior leads to expansive masses of abnormal cells that destroy surrounding normal tissue and can spread to vital organs resulting in disseminated disease, commonly a harbinger of imminent patient death. More significantly, globalization of unhealthy lifestyles, particularly cigarette smoking and the adoption of many features of the modern Western diet (high fat, low fiber content) will increase cancer incidence. (S. Jothi et al.,) Detecting cancer is still challenging for the doctors in the field of medicine. Even now the actual reason and complete cure of cancer is not invented. Various tests are available for predicting cancer, but detecting cancer in earlier stage is difficult, but earlier detection of cancer is curable. In the following sections, previous research, related literatures are discussed.

We have proposed the cancer prediction system based on data mining. Cancer prediction system estimates the risk of the breast, skin, and lung cancers. This system was validated by comparing its predicted results with patient's prior medical information and analyzed using weka system.

\section{PRIOR STUDIES OF CANCER PREDICTION}

Ample of work have been done to predict the risk of the cancer. There are different techniques proposed by different authors for the detection of cancer risk. Each and every method has its own advantages and some disadvantages.

Cancer prediction is certainly a very complex and nondeterministic endeavor so many tests are available for cancer prediction but it's of high cost(Wafa Mokharrak et al.,) Table 1.1 shows the Comparative study of existing Data mining based cancer prediction methods

Table 1.1 Comparative study of existing Data mining based cancer prediction methods

\begin{tabular}{|c|c|c|c|c|}
\hline Authors & Paper & $\begin{array}{c}\text { Technique } \\
\text { used }\end{array}$ & Results & Limitation \\
\hline $\begin{array}{l}\text { Seyyid } \\
\text { Ahmed } \\
\text { Medjahed, } \\
\text { Tamazouzt } \\
\text { Ait Saadi, } \\
\text { Abdelkader } \\
\text { Benyettou } \\
{[2013]}\end{array}$ & \begin{tabular}{|l} 
Breast \\
Cancer \\
Diagnosis \\
by using k- \\
Nearest \\
Neighbor \\
with \\
Different \\
Distances \\
and \\
Classificati \\
on Rules.
\end{tabular} & $\begin{array}{l}1 . \mathrm{K}- \\
\text { Nearest } \\
\text { Neighbors, } \\
2 . \\
\text { Distance, } \\
\text { Classificati } \\
\text { on Rule. }\end{array}$ & $\begin{array}{l}\text { K-NN } \\
\text { method is } \\
\text { used to } \\
\text { diagnose } \\
\text { breast } \\
\text { cancer. The } \\
\text { quality of } \\
\text { the results } \\
\text { depends } \\
\text { largely on } \\
\text { the distance } \\
\text { and the } \\
\text { value of the } \\
\text { parameter } \\
\text { "k" which } \\
\text { represent } \\
\text { the number } \\
\text { of the } \\
\text { nearest } \\
\text { neighbors. } \\
\text { In this } \\
\text { paper, they } \\
\text { study and } \\
\text { evaluate the } \\
\text { performanc } \\
\text { e } \\
\text { different of } \\
\text { distances } \\
\text { that can be } \\
\text { used in the } \\
\text { K-NN } \\
\text { algorithm. } \\
\text { Also, they } \\
\text { analyze this } \\
\text { distance by } \\
\text { using }\end{array}$ & $\begin{array}{l}\text { K-NN } \\
\text { algorithm } \\
\text { works with } \\
\text { Euclidean } \\
\text { distance and } \\
\text { Manhattan. } \\
\text { It gives } \\
\text { better } \\
\text { performanc } \\
\text { e but they } \\
\text { may } \\
\text { consuming } \\
\text { much } \\
\text { amount of } \\
\text { time. } \\
\end{array}$ \\
\hline
\end{tabular}




\begin{tabular}{|c|c|c|c|c|}
\hline Authors & Paper & $\begin{array}{c}\text { Technique } \\
\text { used }\end{array}$ & Results & Limitation \\
\hline & & & $\begin{array}{l}\text { different } \\
\text { values of } \\
\text { the } \\
\text { parameter } \\
\text { "k" and by } \\
\text { using } \\
\text { several } \\
\text { rules of } \\
\text { classificatio } \\
\text { n. }\end{array}$ & \\
\hline $\begin{array}{l}\text { S.Jothi, } \\
\text { S.Anita } \\
\text { [2012] }\end{array}$ & $\begin{array}{l}\text { Data } \\
\text { Mining } \\
\text { Classificati } \\
\text { on } \\
\text { Technique } \\
\text { s Applied } \\
\text { For Cancer } \\
\text { Disease - } \\
\text { A Case } \\
\text { Study } \\
\text { Using } \\
\text { Xlminer. }\end{array}$ & $\begin{array}{l}1 . \\
\text { classificati } \\
\text { on } \\
2 . \\
\text { XLminer }\end{array}$ & $\begin{array}{l}\text { They } \\
\text { Collected } \\
\text { the data } \\
\text { from the } \\
\text { people } \\
\text { according to } \\
\text { their } \\
\text { Symptoms, } \\
\text { and then } \\
\text { they built } \\
\text { theraion } \\
\text { prediction } \\
\text { model } \\
\text { based on the } \\
\text { prior cancer } \\
\text { data set. } \\
\text { This } \\
\text { technique } \\
\text { can be } \\
\text { successfully } \\
\text { applied to } \\
\text { the cancer } \\
\text { such as } \\
\text { Bone } \\
\text { Cancer, } \\
\text { Bladder } \\
\text { Cancer, } \\
\text { Stomach } \\
\text { Cancer, } \\
\text { Kidney } \\
\text { Cancer, and } \\
\text { Uterus } \\
\text { cancer. } \\
\text { They used } \\
\text { XLMiner } \\
\text { tool, it helps } \\
\text { to predict } \\
\text { the cancer } \\
\text { accurately. }\end{array}$ & 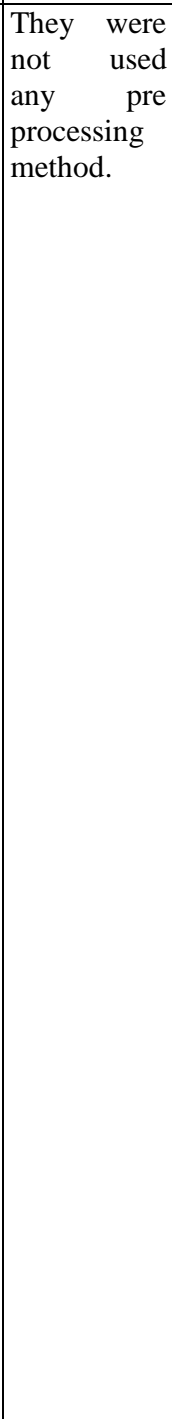 \\
\hline $\begin{array}{l}\text { JulietR } \\
\text { Rajan, } \\
\text { Jefrin } \\
\text { Prakash }\end{array}$ & $\begin{array}{l}\text { Early } \\
\text { Diagnosis } \\
\text { of Lung } \\
\text { Cancer } \\
\text { using a } \\
\text { Mining } \\
\text { System }\end{array}$ & $\begin{array}{l}\text { 1.Artificial } \\
\text { Intelligenc } \\
\mathrm{e} \\
\text { 2.Data } \\
\text { mining }\end{array}$ & $\begin{array}{l}\text { In this paper } \\
\text { they predict } \\
\text { the lung } \\
\text { cancer at an } \\
\text { early stage } \\
\text { thereby } \\
\text { increasing } \\
\text { the survival } \\
\text { rate of the } \\
\text { patient by } \\
\text { five years. } \\
\text { This system } \\
\text { works }\end{array}$ & $\begin{array}{l}\text { They didn't } \\
\text { implement } \\
\text { any system } \\
\text { in online for } \\
\text { predicting } \\
\text { cancer }\end{array}$ \\
\hline
\end{tabular}

\begin{tabular}{|c|c|c|c|c|}
\hline Authors & Paper & $\begin{array}{c}\text { Technique } \\
\text { used }\end{array}$ & Results & Limitation \\
\hline & & & 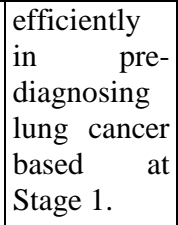 & \\
\hline $\begin{array}{l}\text { Abdelghani } \\
\text { Bellaachia, } \\
\text { Erhan } \\
\text { Guven }\end{array}$ & $\begin{array}{l}\text { Predicting } \\
\text { Breast } \\
\text { Cancer } \\
\text { Survivabili } \\
\text { ty } \\
\text { Using } \\
\text { Data } \\
\text { Mining } \\
\text { Technique } \\
\text { s }\end{array}$ & $\begin{array}{l}\text { 1.Naïve } \\
\text { Bayes, } \\
\text { 2.Backpro } \\
\text { pagated } \\
\text { 3.Neural } \\
\text { network, } \\
\text { 4. C4.5 } \\
\text { decision } \\
\text { tree } \\
\text { algorithm. }\end{array}$ & $\begin{array}{l}\text { They have } \\
\text { analyzed } \\
\text { the } \\
\text { prediction } \\
\text { of } \\
\text { survivabilit } \\
\text { y rate of } \\
\text { breast } \\
\text { cancer } \\
\text { patients } \\
\text { using data } \\
\text { mining } \\
\text { techniques. } \\
\text { They have } \\
\text { used three } \\
\text { data mining } \\
\text { techniques: } \\
\text { Naïve } \\
\text { Bayes, } \\
\text { back- } \\
\text { propagated } \\
\text { neural } \\
\text { network, } \\
\text { and C4.5 } \\
\text { decision } \\
\text { tree } \\
\text { algorithm, } \\
\text { out } \\
\text { which C4.5 } \\
\text { gives better } \\
\text { performanc } \\
\text { e }\end{array}$ & $\begin{array}{l}\text { In this } \\
\text { approach } \\
\text { they did not } \\
\text { include any } \\
\text { methodolog } \\
\text { y to handle } \\
\text { missing } \\
\text { records. }\end{array}$ \\
\hline
\end{tabular}

\section{ARCHITECTURE OF CANCER} PREDICTION SYSTEM

In this work, an architecture data mining technique based cancer prediction system combining the prediction system with mining technology was used. In this model we have used one of the classification algorithms called decision tree. 


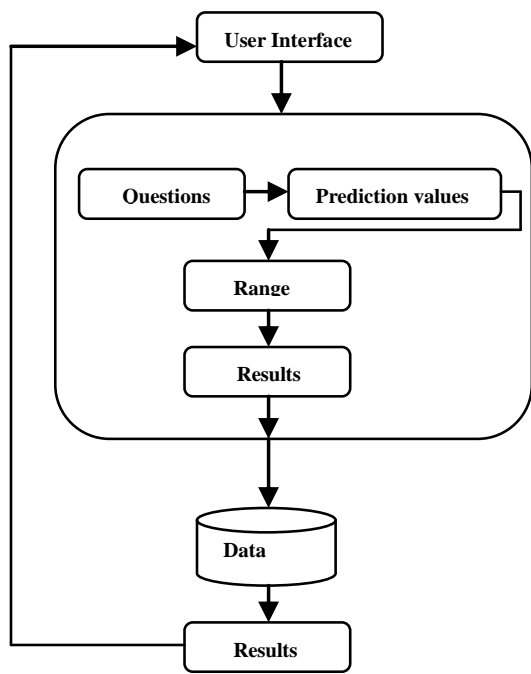

Fig 1.1 Architecture of Cancer prediction system Once the user enters into the cancer prediction system, they need to answer the queries, related to genetic and non genetic factors. Then the prediction system assigns the risk value to each question based on the user responses. Once the risk value is predicted, the range of the risk can be determined by the prediction system.

We have four levels of risk low level, intermediate, high level and very high level. Based on the predicted risk values the range of risk will be assigned. The result can be shown to the user through data base.

\section{Algorithm}

Step 1: Enter the text

Step 2: Predicting system will checks for the condition.

Step 3: System predicts the values based on the user answers.

Step 5: The range of the risk is determined based on the predicted value.

Step 6: If the value is $\leq 18$ the risk is considered as a low risk.

If the value is $18<$ risk value $\leq 21$ the risk is considered as a intermediate risk

If the risk value is $21<$ risk value $\leq 23$ is considered as a high risk.

If the risk value is $>28$ is considered as a very high risk.

Step 6: the user data is stored in data base.

Step 7: The result is shown to the user through data base.

\subsection{Implementing the Architecture of Cancer Prediction System}

In this work we have constructed an expert system called the cancer prediction system which predicts three specific cancer (breast, lung, skin) risks; it helps the user to predict cancer risk level. It can save costs and time. It helps the user to predict their risk and take the necessary steps based on their risk status

This prediction system consists of various functional units listed below:
- Administrator

$\checkmark$ Report

- New user

- User page

$\checkmark \quad$ Prediction test

- Breast cancer

○ Lung cancer

- $\quad$ Feedback

- Skin cancer

This prediction system was implemented by using VB.net and SQL.

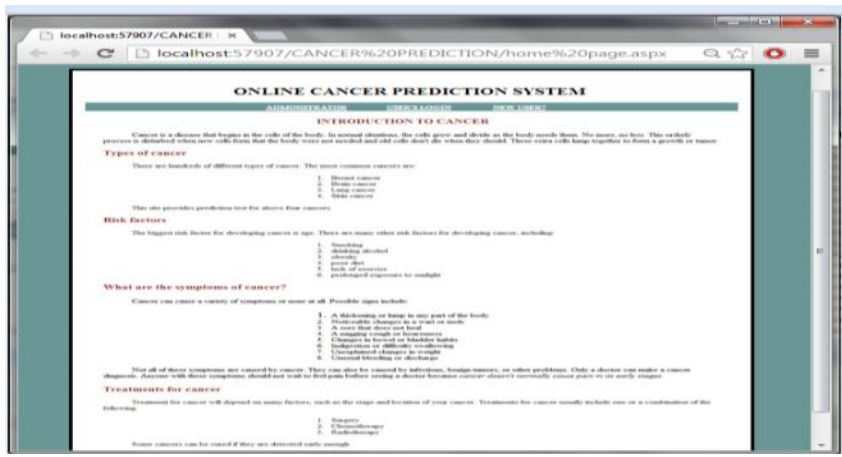

Fig 1.2 Cancer Prediction System

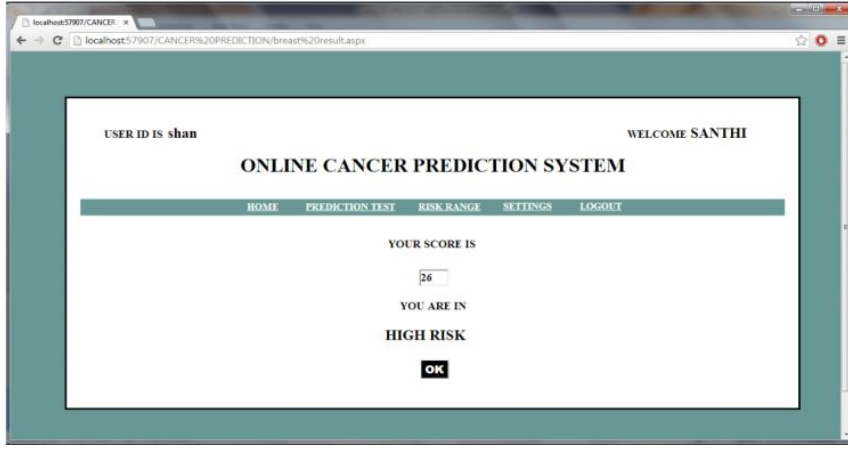

Fig 1.3 Predicting risk of cancer

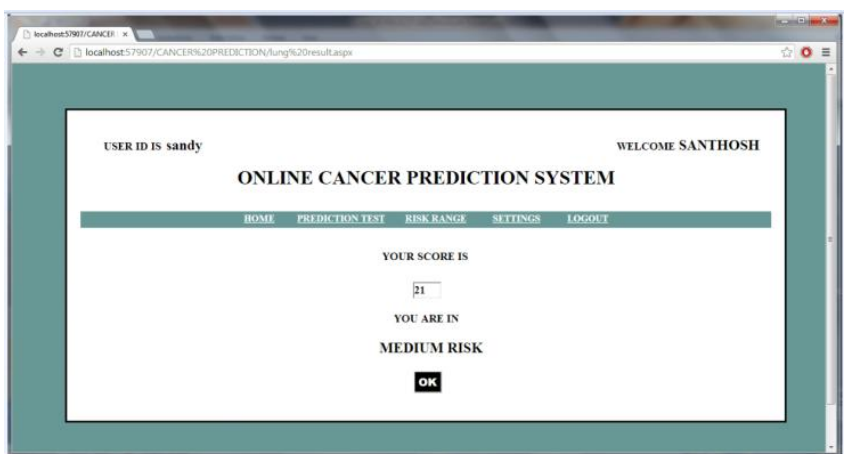

Fig 1.4 predicting risk of cancer 


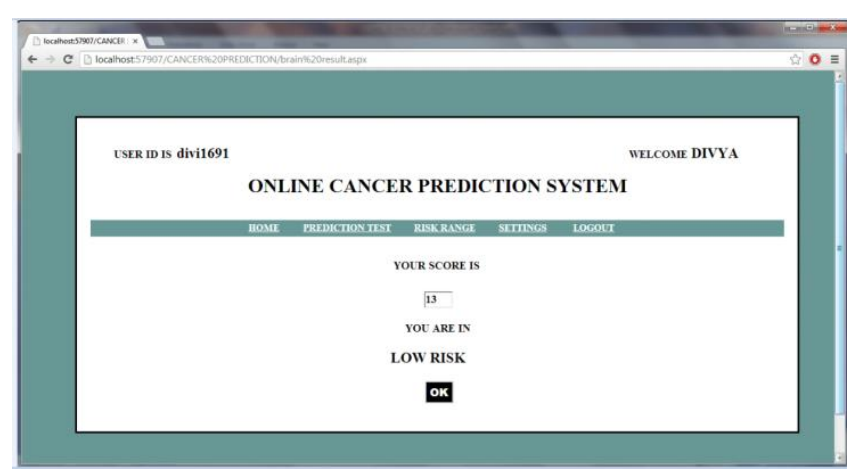

Fig 1.5 predicting risk of cancer

\section{PERFORMANCE EVALUATION OF CANCER PREDICTION SYSTEM}

The effectiveness of cancer prediction system is analyzed in two ways, one is cancer prediction system and another one is analysis of cancer prediction system through weka tool. Data mining based cancer prediction system is used to predict the cancer risks. This system helps the people to know their cancer risk with low cost and it also helps the people to take the appropriate decision based on their cancer risk status. Once the user enters into the cancer prediction system, they need to answer the queries, related to genetic and non genetic factors. Then the prediction system assigns the risk value based on the user responses. Once the risk value is predicted, the range of the risk can be determined by the prediction system. We have four levels of risk low level, intermediate, high level and very high level. The result can be shown to the user through data base. The above mentioned technique can be successfully applied to the data sets for any cancer (such as breast cancer, lung cancer, skin cancer), as it was successfully verified on the breast, lung and skin cancer.

This system was implemented on the web during September and October 2013 people visited this site and we have got feedback from 463 people. The feedback table is shown below. This paper presents how the collected data were analyzed through weka system and the results of data analysis.

Table 1.1 Feedbacks from users

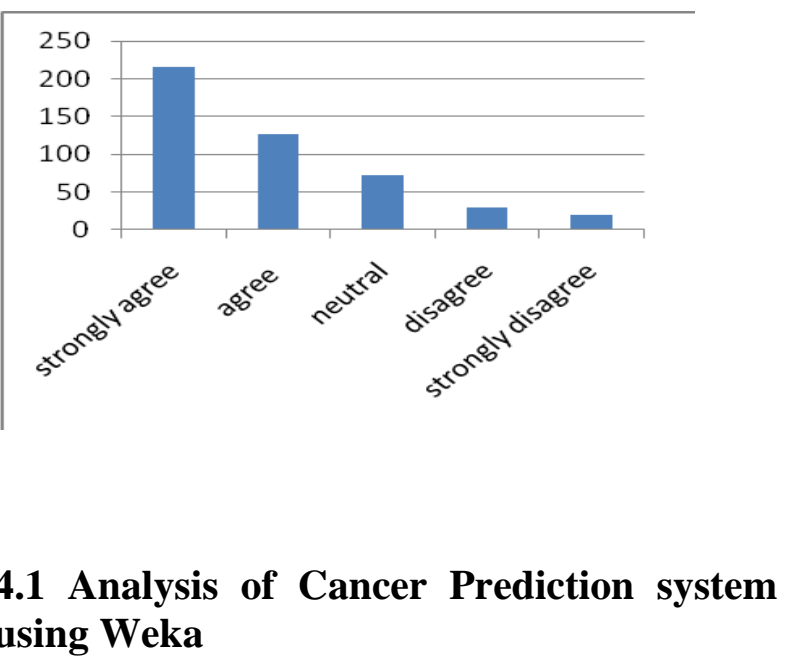

WEKA, formally called Waikato Environment for Knowledge Learning, is a computer program. It supports many different standard data mining tasks such as data preprocessing, classification, clustering, regression, visualization and feature selection. The basic premise of the application is to utilize a computer application that can be trained to perform machine learning capabilities and derive useful information in the form of trends and patterns.

To find the effectiveness of Data mining-based Cancer prediction system author collected data from cancer institute make those data as trained data for cancer prediction system. Then after author collected the data from people during July 2013 to October 2013 and the data is trained through the cancer prediction system architecture.

Based on the previous work author selected 8 attributes as a general attributes and selected some specific attribute for specific cancers. The attributes are listed in the following table 1.2.

Table 1.2 General attributes

\begin{tabular}{|l|l|}
\hline \multicolumn{1}{|c|}{ Attributes } & \multicolumn{1}{|c|}{ Values } \\
\hline Sex & Male $=2$ \\
& Female $=1$ \\
\hline Age & Age $\leq 13=1$ \\
& $13<$ Age $\leq 24=2$ \\
& $24<$ Age $\leq 45=3$ \\
& Age $>45=4$ \\
\hline Affected family members & Yes $=2$ \\
& No $=1$ \\
\hline Consuming greens and & Yes $=1$ \\
vegetables & No $=2$ \\
\hline BMI & $\leq 18=1$ \\
& $18<\mathrm{BMI} \leq 24=2$ \\
& $\geq 24=3$ \\
\hline Affected by any cancer & Yes $=3$ \\
before & No $=1$ \\
\hline Are you a smoker & Yes $=3$ \\
& No $=1$ \\
\hline Are you consuming alcohol & Yes $=3$ \\
& No $=1$ \\
\hline Have you applying hair dye & Yes $=2$ \\
& No $=1$ \\
\hline
\end{tabular}

Table 1.3 attributes of breast cancer

\begin{tabular}{|l|l|}
\hline \multicolumn{1}{|c|}{ Attribute } & \multicolumn{1}{|c|}{ Values } \\
\hline $\begin{array}{l}\text { Multiple family members } \\
\text { who have had breast, ovarian } \\
\text { and/ or prostate cancer }\end{array}$ & Yes $=2$ \\
No $=1$ \\
\hline $\begin{array}{l}\text { Menstrual cycles starts } \\
\text { before 12 }\end{array}$ & Yes $=2$ \\
No $=1$
\end{tabular}


Table 1.4 Attributes of Lung cancer

\begin{tabular}{|l|l|}
\hline Attributes & Values \\
\hline Passive smoker & $\begin{array}{l}\text { Yes }=2 \\
\text { No }=1\end{array}$ \\
\hline Lived in city & $\begin{array}{l}\text { Yes }=2 \\
\text { No }=1\end{array}$ \\
\hline Working with chemicals & $\begin{array}{l}\text { Yes without } \\
\text { protection }=3 \\
\text { Yes with } \\
\text { protection }=2 \\
\text { No }=1\end{array}$ \\
\hline $\begin{array}{l}\text { Radiation therapy to chest } \\
\text { area }\end{array}$ & $\begin{array}{l}\text { Yes }=3 \\
\text { No }=1\end{array}$ \\
\hline $\begin{array}{l}\text { Consumed tobacco } \\
\text { Yes }=3 \\
\text { No }=1\end{array}$ \\
\hline $\begin{array}{l}\text { Have you suffered from any } \\
\text { chronic diseases }\end{array}$ & $\begin{array}{l}\text { Yes }=3 \\
\text { No }=1\end{array}$ \\
\hline
\end{tabular}

Table 1.5 Attributes of Skin cancer

\begin{tabular}{|l|l|}
\hline Attributes & Values \\
\hline Outdoor activities & $\begin{array}{l}\text { Frequent = 3 } \\
\text { Medium = 2 } \\
\text { No = 1 }\end{array}$ \\
\hline Color of skin & $\begin{array}{l}\text { Black =1 } \\
\text { white =2 }\end{array}$ \\
\hline Working period in industries & $\begin{array}{l}\text { More than 5 hours } \\
=3 \\
\text { Less than 5 hours } \\
=2 \\
\text { No=1 }\end{array}$ \\
\hline Protect yourself from sun & $\begin{array}{l}\text { Yes }=1 \\
\text { No=2 }\end{array}$ \\
\hline
\end{tabular}

\subsection{Performance analysis of cancer prediction system}

We have chosen two data mining techniques to find the effectiveness of cancer prediction system they are navie bayes, and decision tree.

\subsubsection{Decision tree}

The decision tree algorithm is one of the popular algorithm for classification problems. In decision tree, rules are extracted from the training dataset to form a tree structure, and this rule will be applied to the classification of testing data. There are many popular decision tree algorithms CART, J48, ID3, C4.5, and CHAID. In this paper we have chosen J48 and ID3 for performance analysis. The J48 algorithm recursively classifies data until it has been classified as perfectly. This technique gives maximum accuracy on training data. The experiments run on a smaller dataset.

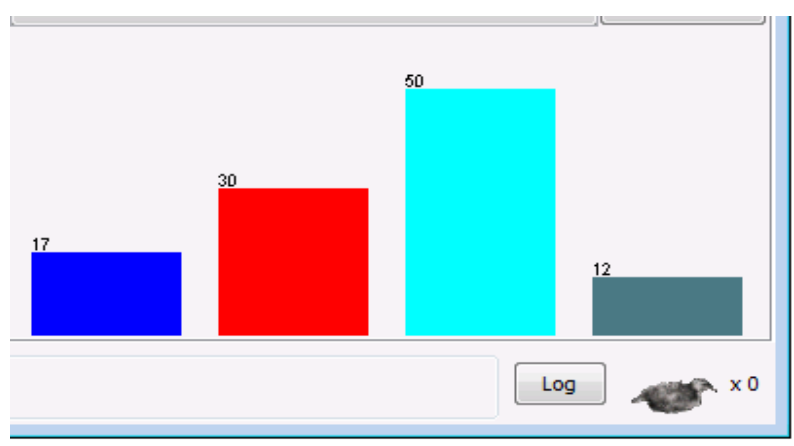

Graph 1.1 Results of breast cancer using J48

In the graph ash color bar represents the very high cancer risk, blue color represents high risk, red color represents the intermediate cancer risk, cyan represent the low risk.

ID3

ID3 builds a decision tree from a fixed set of samples. The resulting tree is used to classify future dataset. The leaf nodes of the decision tree contain the class name whereas a non-leaf node is a decision node.

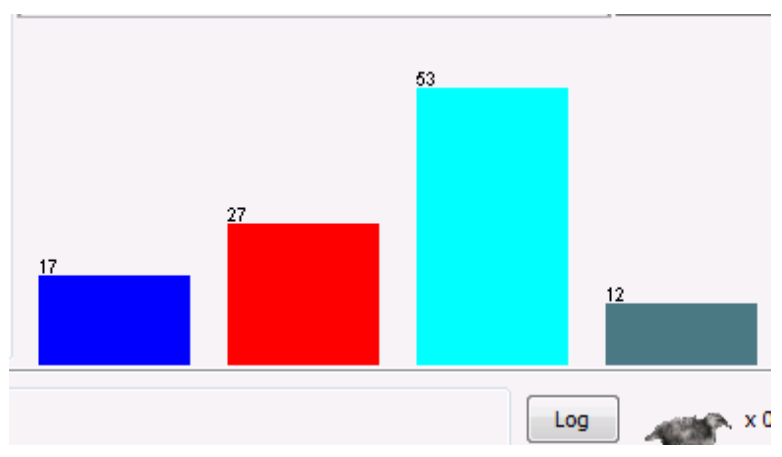

Graph 1.2 Results of breast cancer using ID3

Navie bayes

Navie Bayes model is a simple and well known method for performing supervised learning of a classification problem. The Navie Bayesian Classifier make the assumption of class conditional independence, i.e, given the class label of a tuple, the values of the attributes are assumed to be conditionally independent of one another.

Graph 1.3 Results of breast cancer using Navie bayes

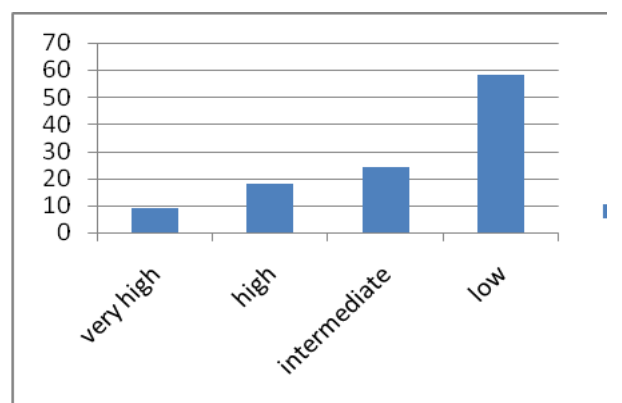


Table 1.6 Accuracy table for breast cancer

\begin{tabular}{|l|l|l|l|}
\hline weka & $\mathrm{J} 48$ & ID3 & navie bayes \\
\cline { 2 - 4 } & $98.16 \%$ & $100 \%$ & $86.23 \%$ \\
\hline
\end{tabular}

ID3 algorithm provides highest accuracy in breast cancer prediction.

\section{J48}

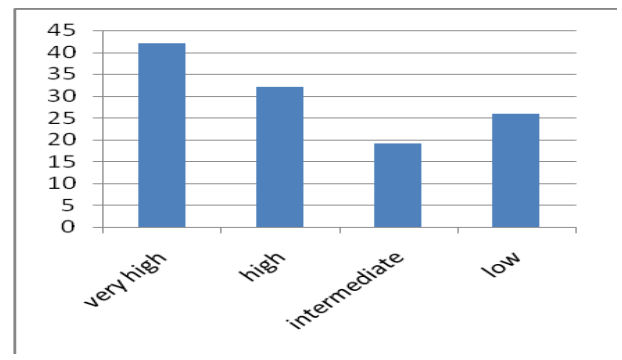

Graph 1.4 Results of lung cancer using J48

\section{ID3}

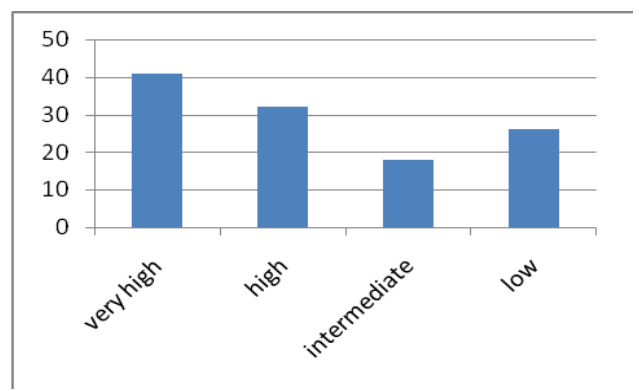

Graph 1.5 Results of lung cancer using Id3

\section{Navie bayes}

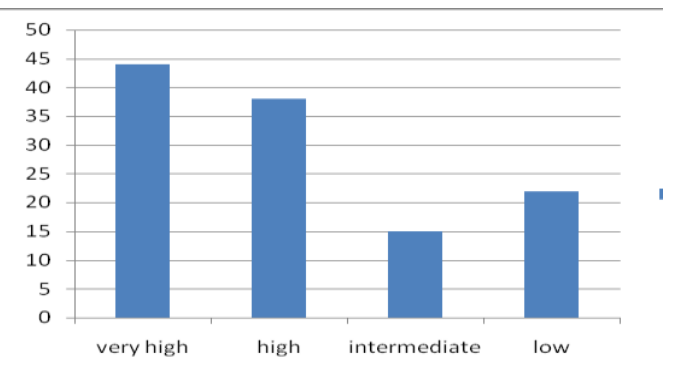

Graph 1.6 Results of lung cancer using Navie Bayes

Table 1.7 accuracy prediction for lung cancer

\begin{tabular}{|l|l|l|c|}
\hline weka & J48 & ID3 & navie bayes \\
\cline { 2 - 4 } & $98.31 \%$ & $100 \%$ & $89.03 \%$ \\
\hline
\end{tabular}

ID3 algorithm provides highest accuracy in lung cancer prediction.
J48

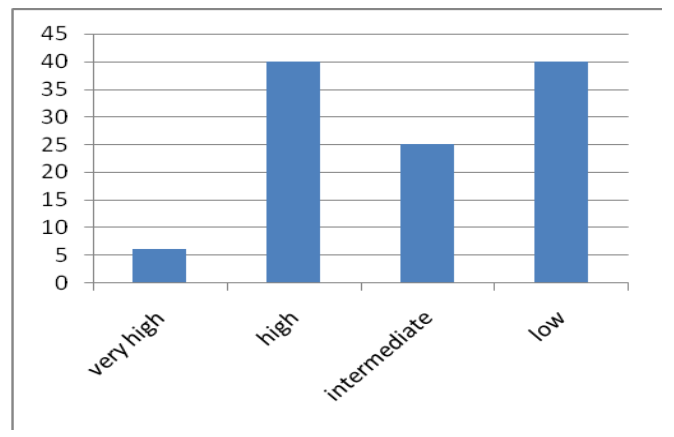

Graph 1.7 Results of skin cancer using J48

ID3

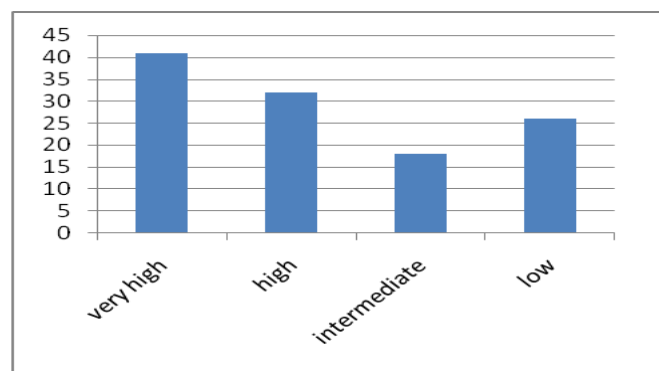

Graph 1.8 Results of skin cancer using Id3

Navie bayes

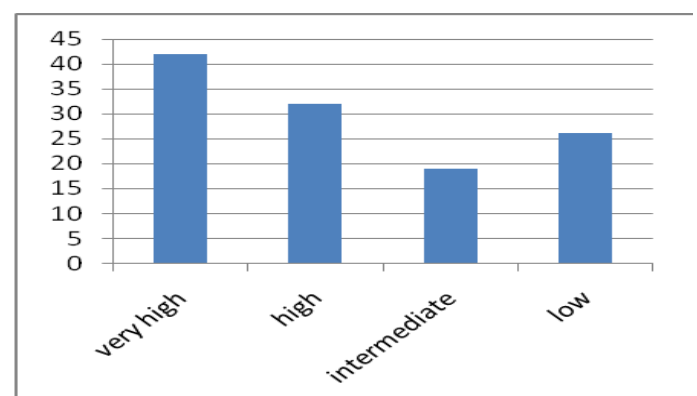

Graph 1.9 Results of skin cancer using Navie Bayes

Table 1.8 Accracy table for skin cancer

\begin{tabular}{|l|l|l|l|}
\hline \multirow{2}{*}{ weka } & J48 & ID3 & navie bayes \\
\cline { 2 - 4 } & $80 \%$ & $100 \%$ & $78.3 \%$ \\
\hline
\end{tabular}

ID3 algorithm provides highest accuracy in skin cancer prediction.

\section{CONCLUSION}

Cancer is potentially fatal disease. Detecting cancer is still challenging for the doctors in the field of medicine. Even now the actual reason and complete cure of cancer is not invented.

Detection of cancer in earlier stage is curable. In this work we have developed a system called data mining based cancer prediction system. The main aim of this model is to provide the earlier warning to the users, and it is also cost and time benefit to the user. It predicts three specific cancer risks. Specifically, Cancer prediction system estimates the risk of 
the breast, skin, and lung cancers by examining a number of user-provided genetic and non-genetic factors. This system is validated by comparing its predicted results with the patient's prior medical record, and also this is analyzed using weka system. This prediction system is available in online, people can easily check their risk and take appropriate action based on their risk status. This system performs well than the existing system.

\section{REFERENCES}

[1] N.Revathy, Dr.R.Amalraj(2011) Accurate Cancer Classification using Expression of Very few Genes. International Journal of Computer Application Volume $14-$ No.4.

[2] Tasnuba Jesmin, Kaswar Ahmed, Md. Badrul Alam Miah (2013) Brain Cancer Risk Prediction System Using Data mining. International Journal of Computer Applications, Volume 61- No.

[3] Seyyid Ahmed Medjahed, Tamazouzt Ait Saadi, Abdelkader Benyettou (2013) Breast Cancer Diagnosis using K-Nearest Neibhor with Different Distances And Classification Rules. International Journal of Computer Applications, Volume 62- N0.1.

[4] Wafa Mokharrak, Nedhal Al Khalaf, Tom altman Application of Bioinformatics and Data mining in Cancer Prediction.

[5] Kawasar Ahmed, Tanuba Jesmin, Md.Zamilur Rahman (2013)Early Prevention and Detection of Skin Cancer using Data mining. International Journal of Computer Application, Volume 62-No.4.

[6] Abdelghani Bellachia, Erhan Guven Predicting Breast Cancer Survivablity Using Data mining Techniques.

[7] S. Jothi, S.Anitha (2012) Data mining Classification Techniques Applied Fo Cancer Disease - A case Study
Using Xlminer. International Journal of Engineering Research \& Technolgy, Vol 1 Issue 8.

[8] V.Kroshnaiah, Dr.G.Narsimha, Dr.N.Subhash Chandra (2013) Diagnosis of Lung Cancer Prediction System Using Data mining Classification Techniques International Journal Of Computer Science And Information Technologies, Vol 4(1), 39-45.

[9] Ada Ranjneet Kaur (2013) A Study of Lung Cancer Using Data mining Classification Techniques. International Journal of Advanced Research in Computer Science and Software Engineering, Vol 3, Issue 3.

[10] K.Rama Lakshmi and S.Prem Kumar (2013) Utilization of Data mining Techniques for Prediction and Diagnosis of Major Life Threatening Diseases SurvivabilityReview International Journal of Scientific \& Engineering Research, Vol 4, Issue 6.

[11] Juliet R.Rajan, Jefrin J Prakash Early Diagnosis of Lung Cancer using a Mining System IJETTCS.

[12] E.Barati, M.Saraee, A.Mohammadi, N.Adibi and M.R.Ahamadzadeh (2011) A Survwy on Utilization of Data mining Approaches for Dermatological (Skin) Diseases Prediction Cyber Journals: Multidisciplinary Journals in Science and Technology, Journal of Selected Areas in Health Informatics.

[13] Charalampos Mavroforakis Data mining with WEKA a use-case to help you gets started.

[14] Jiawei Han and Micheline Kamber Data mining Concepts and Techniques,Second Edition.

[15] Calculate your risk.Australian Government [Oneline]. Available: http://canceraustralia.nbocc.org.au/risk/caculator.php 110-115. 